Sari Pediatri, Vol. 6, No. 1, Juni 2004: 2-9

\title{
Hubungan vaksin Measles, Mumps, Rubella (MMR) dengan Kejadian Autisme
}

\author{
Elsye Souvriyanti, Sri Rezeki S. Hadinegoro
}

\begin{abstract}
Kejadian autisme yang dihubungkan dengan pemberian vaksin MMR mulai menjadi pembicaraan dan mendapat perhatian besar dari kalangan medis dan orang tua sejak penelitian oleh Dr. Andrew Wakefield dkk. dipublikasi di Inggris tahun 1998. Dampak dari pemberitaan ini orang tua menjadi cemas untuk memberikan vaksinasi MMR pada anaknya, dan orang tua yang mempunyai anak autisme menghubungkan kejadian penyakit anaknya dengan riwayat pemberian vaksin MMR. Dokter juga menjadi raguragu untuk memberikan vaksin MMR pada anak. Beberapa penelitian telah dilakukan untuk mencermati adanya hubungan antara pemberian vaksin MMR dengan kejadian autisme. Penelitian dilakukan baik berupa laporan kasus, kasus serial, dan penelitian epidemiologis dengan atau tanpa kontrol. Di antara penelitian-penelitian tersebut selanjutnya dipublikasikan untuk melihat adanya korelasi tersebut. Hasil penelitian menunjukkan adanya pro dan kontra mengenai pendapat Dr. Andrew Wakefield dkk. Sebagian besar menunjukkan bahwa tidak ada hubungan kausal antara kejadian autisme dengan pemberian vaksin MMR. Bahkan para ahli di WHO menyimpulkan bahwa penelitian Dr. Andrew Wakefield dkk. telah gagal dalam membuktikan hubungan kausal antara vaksin MMR dengan autisme. Meskipun demikian, tetap masih menjadi pertanyaan yang perlu jawaban untuk menyingkirkan kemungkinan vaksin MMR dapat menyebabkan autisme pada sejumlah anak tertentu.
\end{abstract}

Kata kunci: vaksin, vaksin kombinasi, $M M R$, autisme

$C$ munisasi telah terbukti merupakan intervensi pencegahan yang paling efektif dalam menurunkan angka kematian dan kesakitan. Di Indonesia program imunisasi telah berhasil membasmi penyakit cacar dan telah dinyatakan bebas cacar pada tahun 1974. Dalam waktu dekat polio eradikasi dari negeri kita. Penggunaan vaksin dalam imunisasi selain adanya alasan epidemiologi penyakit,

Alamat Korespondensi:

Prof. DR. Dr. Sri Rezeki S Harun Hadinegoro, Sp.A(K).

Kepala Subbaggian Infeksi dan Penyakit Tropis. Bagian Ilmu Kesehatan Anak FKUI-RSCM, Jakarta. Jl. Salemba no. 6, Jakarta 10430.

Telepon: 021-391 4126. Fax. 3907743.

Dr. Elsye Souvriyanti PPDS Bag Ilmu Kesehatan Anak FKUI harus ada bukti bahwa vaksin tersebut efektif dan relatif aman digunakan. Risiko penyakit yang dicegah harus lebih besar dari pada risiko prosedur imunisasi. Salah satu isu yang berkembang saat ini adalah autisme yang dikaitkan dengan pemberian vaksin MMR. ${ }^{1-7}$

Vaksin MMR merupakan vaksin kombinasi yang terbuat dari mikroorganisme yang dilemahkan (live attenuated), sehingga diharapkan reaksi samping berkurang dan terjadi pembentukan zat anti yang menyerupai infeksi alamiah. Vaksinasi MMR telah berhasil menurunkan kejadian penyakit campak, gondongan, dan rubela. Di Amerika Serikat angka kejadian penyakit campak menurun dari 400.000 per tahun pada sebelum era adanya vaksinasi dibanding hanya 100 kasus pada tahun 1999.5 
Saat ini dugaan akan adanya hubungan antara vaksin MMR dengan risiko kejadian autisme mendapat perhatian yang besar, baik dari orang tua maupun kalangan medis. ${ }^{1-7}$ Penelitian yang dilakukan oleh Dr. Andrew Wakefield dkk. terhadap 12 anak dengan keluhan gastrointestinal yang disertai dengan keterlambatan perkembangan, 8 di antaranya menderita autisme yang menurut orang tua atau dokternya terjadi dalam 1 bulan setelah mendapat vaksin $M^{2}{ }^{2}$. Virus campak ditemukan pada ileum terminal anak dengan keterlambatan perkembangan mental yang disertai keluhan gastrointestinal, tetapi tidak ditemukan pada anak normal dengan keluhan gastrointestinal yang sama. ${ }^{4-6}$ Virus campak yang terdapat pada vaksin MMR merupakan virus hidup yang dilemahkan yang pada keadaan normal tidak menyebabkan timbulnya gejala penyakit atau hanya dapat menimbulkan gejala yang sangat ringan. Walaupun demikian tipe virus yang liar dapat menginfeksi susunan syaraf pusat dan menyebabkan ensefalomielitis yang diduga disebabkan oleh respons imun terhadap protein mielin. ${ }^{5-8}$

Banyak penelitian yang dilakukan untuk membuktikan adanya hubungan antara vaksin MMR dengan autisme di antaranya berupa serial kasus, ${ }^{2,9-11}$ studi epidemiologi, ${ }^{11-14}$ atau studi cross- sectional. ${ }^{15}$ Salah satu alasan utama adanya perhatian dari masyarakat terhadap kejadian ini adalah sejalan dengan semakin luasnya pemakaian vaksin MMR dan sejalan dengan peningkatan terjadinya prevalensi autisme. ${ }^{13}$ Konsekuensi dari kejadian ini adalah banyak di antara orang tua yang ragu untuk memberikan vaksin MMR pada anaknya sehingga risiko untuk mendapatkan penyakit akan besar dan kemungkinan untuk eradikasi penyakit menjadi terlambat. Penelitian yang menolak adanya hubungan antara vaksin MMR dan autisme didasarkan atas terjadinya peningkatan kasus autisme tanpa diikuti meningkatnya jumlah pemakaian vaksin MMR. ${ }^{1,10,11,12}$ dan tidak terjadi peningkatan kasus autisme pada anak yang mendapat vaksin MMR dibandingkan dengan yang anak tidak mendapat vaksin MMR. ${ }^{14,32}$

Di Indonesia belum ada data yang membuktikan mengenai hubungan antara vaksin MMR dengan kejadian autisme. Tujuan dari tulisan ini adalah untuk membahas vaksin kombinasi MMR, tinjauan autisme secara singkat, dan menyimpulkan pendapat para ahli tentang hubungan pemberian vaksin MMR dan kejadian autisme.

\section{Tinjauan Umum Imunisasi}

\section{Vaksin Kombinasi}

Vaksin kombinasi merupakan gabungan beberapa antigen tunggal menjadi satu jenis produk antigen untuk mencegah penyakit yang berbeda (misalnya vaksin DPT yang digabung dengan vaksin hepatitis B) atau antigen dari galur multipel dari organisme penyebab penyakit yang sama (misalnya vaksin polio OPV terdiri dari gabungan virus polio galur $1,2,3) \cdot{ }^{16,17}$ Komponen yang terdapat dalam vaksin kombinasi terdiri dari antigen, ajuvan, dan preservasi. Antigen yang dapat menginduksi terbentuknya zat anti akibat adanya infeksi disebut sebagai antigen protektif yang didapat dengan melakukan ekstraksi dari sel bakteri atau partikel virus yang digunakan untuk pembuatan vaksin sehingga komponen toksiknya dapat dihilangkan dan vaksin aman untuk digunakan. Antigen protektif ini dapat menginduksi terbentuknya IgM dan IgG, yang merupakan respon imun tubuh terhadap pajanan antigen. Preservasi merupakan zat pengawet vaksin misalnya timerosal, 2-phenoxyethanol yang dapat meningkatkan imunogenisitas, reaktogenisitas, dan stabilisasi dari vaksin ${ }^{18}$.

Alasan utama pembuatan vaksin kombinasi adalah untuk mengurangi biaya pengobatan dan pemakaian vaksin, sebagai proteksi terhadap beberapa penyakit sehingga jumlah suntikan dan jumlah kunjungan dapat dikurangi, meningkatkan compliance dan cakupan imunisasi, dapat mengejar imunisasi yang terlambat, dan memudahkan menambahkan vaksin lain ke dalam program imunisasi yang telah ada. ${ }^{16,17,21}$ Diantara keuntungan pemakaian vaksin kombinasi, juga terdapat kerugian yaitu, terjadinya ketidakserasian (incompatibility) kimia/fisis akibat pencampuran beberapa antigen beserta ajuvannya, sulit dihindari adanya perubahan respons imun (imunogenitas) sebagai akibat interaksi antara antigen dengan antigen lain atau antara antigen dengan ajuvan yang berbeda, kemungkinan meningkatnya kejadian ikutan pasca imunisasi (KIPI), pemakaian vaksin kombinasi dapat membingungkan para dokter dalam menyusun jadwal imunisasi ${ }^{16,17}$.

\section{Vaksin MMR}

Mumps measles rubella merupakan vaksin untuk mencegah penyakit gondongan (mumps), campak 
(measles) dan rubela. Vaksin MMR merupakan vaksin live attenuated yang dibuat dari virus atau bakteri liar penyebab penyakit. Mikroorganisme vaksin yang dihasilkan masih memiliki kemampuan untuk tumbuh (replikasi) dan menimbulkan kekebalan tetapi tidak menyebabkan penyakit. Saat ini di Indonesia terdapat dua jenis vaksin yang beredar yaitu MMR $\mathrm{II}^{\circledR}(\mathrm{MSD})$ dan Trimovax ${ }^{\circledR}$ (Aventis Pasteur).

Vaksin MMR diberikan pada umur 15-18 bulan, dosis satu kali $0.5 \mathrm{ml}$ subkutan dalam atau intramuskular. Ulangan diberikan pada umur 10-12 tahun atau 12-18 tahun. Vaksin MMR diberikan minimal 1 bulan setelah penyuntikan dengan kuman atau virus hidup lain. Pemberian vaksin MMR akan menurunkan risiko kejadian penyakit gondongan, campak, dan rubella serta komplikasi yang dapat ditimbulkannya. (Tabel 1) vaksin virus hidup) dalam waktu 4 minggu. Pada pasien tuberkulosis atau uji tuberkulin positif, uji tuberkulin bersamaan dengan vaksinasi, menyusui, kehamilan, infeksi HIV tanpa imunosupresi berat, alergi telur, reaksi non anafilaksis terhadap neomisin bukan indikasi kontra untuk pemberian vaksin MMR. ${ }^{22,24}$ Perhatian khusus diberikan pada anak yang mendapat tranfusi darah/produk darah atau imunoglobulin (3-11 bulan), trombositopenia, dan riwayat purpura trombositopenia.

\section{Penelitian kontroversi Dr.Andrew Wakefield tentang hubungan vaksin MMR dengan kejadian autisme}

Pada tahun 1988, Andrew Wakefield dkk, seorang

Tabel 1. Perbandingan angka morbiditas campak, gondongan dan rubella pada anak yang tidak divaksin dibandingkan angka morbiditas tahun 2000 di Amerika Serikat ${ }^{23}$

\begin{tabular}{lcccc}
\hline Penyakit & Tahun & $\begin{array}{c}\text { Morbiditas } \\
\text { sebelum vaksinasi }\end{array}$ & $\begin{array}{c}\text { Morbiditas th 2000 } \\
\text { sesudah vaksinasi }\end{array}$ & $\begin{array}{c}\text { Tingkat penurunan } \\
(\%)\end{array}$ \\
\hline Campak & $1958-1962$ & 503.282 & 81 & 100 \\
Gondongan & 1968 & 152.209 & 323 & 99,8 \\
Rubella & $1966-1968$ & 47.745 & 152 & 99,7 \\
\hline
\end{tabular}

Sumber : JAMA 2002;288:3155-8 23

\section{Kejadian ikutan pasca imunisasi}

Kejadian ikutan pasca imunisasi MMR yang pernah dilaporkan adalah terjadinya malaise, demam atau ruam yang terjadi 1 minggu setelah imunisasi yang berlangsung selama $2-3$ hari, kejang demam pada $0,1 \%$ anak yang terjadi pada minggu ke-2, ensefalitis pasca imunisasi 1/1.000.000 dosis vaksin yang terjadi pada minggu ke-3 dan pembengkakan kelenjar parotis $1 \%$ anak berusia sampai 4 tahun. Meningoensefalitis yang disebabkan oleh imunisasi gondongan terjadi kira-kira 1/1.000.000 dosis vaksin dengan galur virus gondongan Urabe. Angka kejadian ini lebih kecil dibandingkan menggunakan galur virus Jeryl Lyn. ${ }^{22}$

Kontra indikasi pemberian vaksin MMR pada keadaan adanya reaksi anafilaksis terhadap neomisin atau gelatin, kehamilan, imunodefisiensi (keganasan hematologi atau tumor padat, terapi imunosupresan jangka panjang, infeksi HIV), demam akut, anak yang mendapat vaksin hidup lain (termasuk BCG dan doktor di bidang gastroenterologi dari Royal Free hospital di London mempublikasikan laporan penelitian di majalah Lancet yang berjudul Ileallymphoid hyperplasia, non-specific colitis, and pervasive development disorder in children. Penelitian dilakukan terhadap 12 anak usia 3-10 tahun dengan gangguan perkembangan neurologis disertai keluhan gastrointestinal, 8 di antaranya menderita autisme yang orang tua atau dokternya memperkirakan bahwa gejalagejalanya terjadi 1 bulan setelah mendapat vaksin MMR. ${ }^{2}$ Andrew Wakefield mengemukakan hipotesis bahwa vaksin MMR menyebabkan inflamasi intestinal, hilangnya fungsi barier usus (leaky bowel), masuknya protein ensefalopatik ke dalam aliran darah sehingga terjadilah autisme. Meskipun demikian Wakefield sendiri mengakui bahwa hubungan kausal tersebut belum terbukti dan mengisyaratkan perlunya penelitian lanjutan. ${ }^{2}$

Pada tahun 2002, Dr. Andrew Wakefield dan O'Leary ahli patologi melaporkan penelitian mereka 
yang kedua mengenai hubungan virus morbili dan autisme. Dalam penelitian tersebut diperiksa sampel biopsi usus dari total 160 anak yang menderita autisme dan yang tidak, terdapat adanya genom virus morbili pada pemeriksaan reverse transcriptase polymerase chain reaction (RT-PCR) dan insitu hybridization. Hasilnya menunjukkan bahwa pada 75 di antara 90 anak autisme ditemukan genom virus morbili di dalam jaringan biopsi ususnya dibandingkan hanya 5 di antara 70 anak yang bukan autisme (kontrol). ${ }^{4}$

Sejak dikemukakannya laporan penelitian pertama oleh Andrew Wakefield angka imunisasi MMR di Inggris menurun. Dampaknya tak hanya di Inggris, bahkan di seluruh dunia para ahli mulai membicarakan hal ini.

\section{Penelitian yang mendukung pendapat Andrew Wakefield}

Laporan kasus dari Vaccine Adverse Event Reporting System (VAERS), yang merupakan sistem survailens pasif di Amerika Serikat. Laporan dikumpulkan dari Januari 1990-Januari 1991, didapatkan 291 kasus yang melibatkan vaksin MMR atau vaksin lain yang mengandung morbili yang berhubungan dengan kejadian autisme, gangguan bicara, mental retardasi, schizoprenia, kolitis, ileitis, enteritis atau gangguan saluran cerna. Laporan kasus ini dinilai kurang informatif untuk menggambarkan hubungan sebab akibat karena dengan sistem survailens pasif banyak kasus yang tidak dilaporkan kurang terinci dan kriteria diagnostiknya konsisten ${ }^{30}$.

Kawashima dkk. pada tahun 2000 menemukan bahan genetik dalam sel mononuklear perifer kasus inflammatory bowel disease dan penderita autisme dengan kelainan usus. Pemeriksaan dilakukan dengan RT-PCR, sequence genetik virus morbili yang ditemukan ternyata lebih sesuai dengan vaccine strain. ${ }^{31}$ Timothy Buie pada tahun 2001 melakukan endoskopi gastrointestinal, dan pemeriksaan enzim pencernaan pada 400 anak autisme. Hasil pemeriksaan enzim pencernaan menunjukkan $55 \%$ anak mengalami defisiensi enzim laktase dan sukrase. Hasil biopsi pada 89 anak menunjukkan adanya inflamasi kronik pada saluran cerna berupa esofagitis, gastritis dan enterokolitis pada 15 anak. $^{30}$

The medicines control agency, suatu kelompok kerja di Inggris meninjau dan menilai kembali laporan kasus anak yang menderita autisme, Crohn's disease atau gangguan serupa setelah mendapat vaksin MMR. Hasil evaluasi menunjukkan bahwa 8 di antara 92 kasus autisme dan 4 dari 15 kasus Crohn's disease mempunyai hubungan yang dekat antara pemberian vaksin dengan timbulnya gejala dan tidak ditemukan adanya penyebab lain. Kelompok kerja ini berkesimpulan belum dapat disingkirkan dugaan hubungan antara vaksin MMR dan autisme mengingat adanya bias seleksi dan tidak adanya kontrol. ${ }^{30}$

\section{Penelitian yang menolak pendapat Andrew Wakefield}

Peltoha dkk. pada tahun 1998 melakukan penelitian retrospektif di Finlandia dengan mengikuti efek samping yang terjadi setelah pemberian vaksin MMR selama 10 tahun. Jumlah anak yang divaksinasi MMR sebanyak 3 juta di antaranya 31 mengalami gejala gastrointestinal tetapi tidak ada yang berkembang menjadi autisme. ${ }^{10}$ Taylor dkk. pada Juni 1999 mempublikasikan hasil penelitian setelah meneliti arsip 498 anak autisme di Inggris sebelum dan sesudah vaksinasi MMR dimulai di Inggris tahun 1998. Penelitian dilakukan secara serial kasus yang merupakan studi epidemiologi, dengan memperhatikan kejadian dan usia diagnosis autisme pada anak yang divaksin dan yang tidak. Penelitian ini tidak mendukung adanya hubungan kausal antara vaksin MMR dan autisme ${ }^{11}$.

Penelitian time trend analysis yang dilakukan oleh Kaye JA dkk di Inggris menyimpulkan bahwa tidak ada hubungan kausal antara kejadian vaksinasi MMR dengan diagnosis autisme yang meningkat tahun 19881999. Pada penelitian ini didapatkan peningkatan kasus yang didiagnosa sebagai autisme di antara anak usia $<12$ tahun sebanyak 7 kali lipat dari 0,3 per 10.000 penduduk pada tahun 1988 menjadi 2,1 per 10.000 penduduk pada tahun 1999 (Gambar 1). Usia rata-rata saat pertama kali didiagnosis sebagai autisme pada usia 4 tahun 6 bulan. Puncak usia saat pertama kali didiagnosis antara 3-4 tahun ${ }^{1}$.

Di antara 305 anak yang menderita autisme, 248 anak adalah laki-laki. Risiko kejadian autisme meningkat 4 kali di antara anak usia 2-5 tahun yang lahir pada tahun 1988-1993 (Gambar 2); tetapi pada kurun waktu yang sama proporsi anak yang mendapat vaksin MMR tetap sekitar 95\%.

Peningkatan diagnosis autisme ini lebih disebabkan karena kewaspadaan dari orang tua dan dokter 


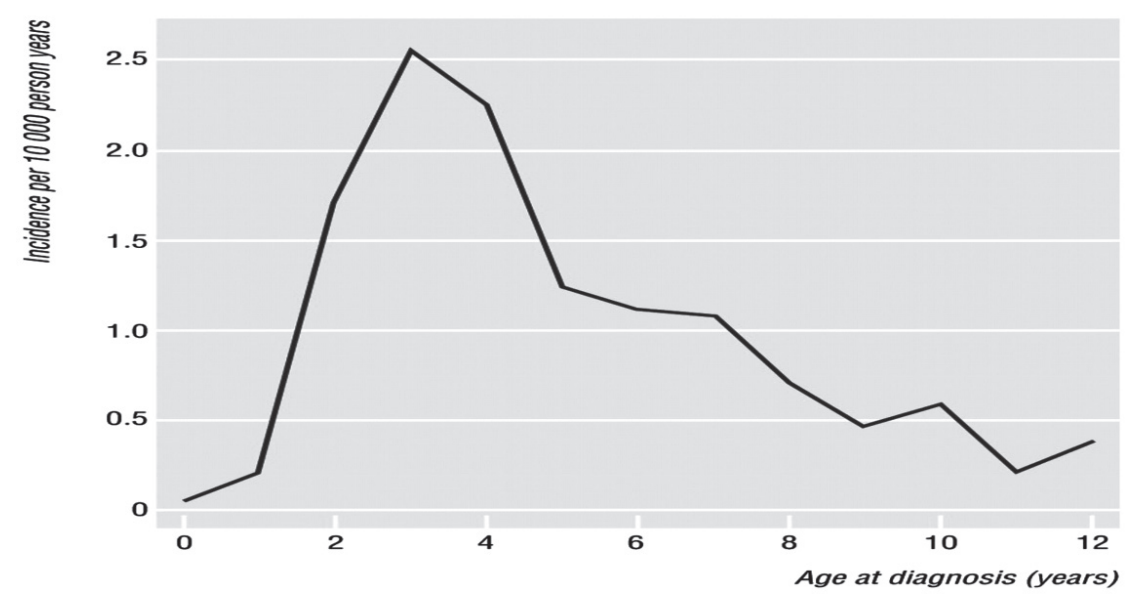

Gambar 1. Insidensi autisme di Inggris berdasarkan usia saat diagnosa Sumber : BMJ 2001; 322:461 ${ }^{1}$

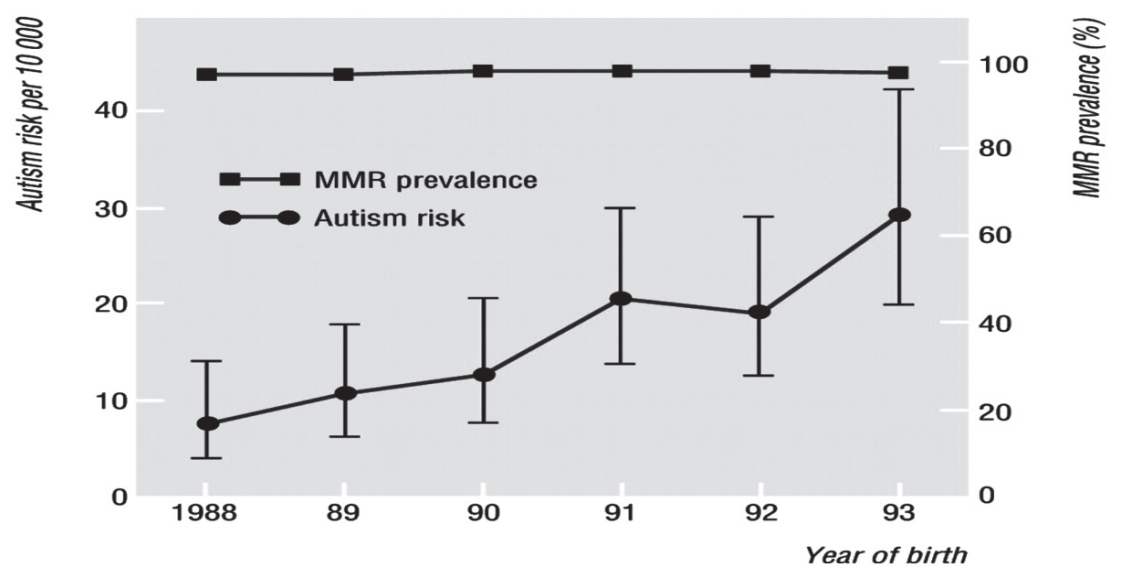

Gambar 2. Peningkatan resiko kejadian autisme di antara anak lakilaki usia 2-5 tahun dan prevalensi MMR Sumber: BMJ 2001; 322:462 ${ }^{1}$

terhadap kejadian autisme dan tidak berhubungan dengan pemberian vaksin MMR. ${ }^{1}$ Penelitian retrospektif di California oleh Dales dkk, menggambarkan hubungan antara anak yang menerima vaksin MMR dan kejadian autisme dari tahun 19801994. (Gambar 3)

Meskipun angka kejadian autisme meningkat secara drastis, persentase anak yang menerima vaksin MMR tidak berubah, sehingga para peneliti berkesimpulan tidak ada hubungan antara imunisasi MMR dengan peningkatan kasus autisme. ${ }^{12}$
Madsen KM dkk di Denmark melakukan penelitian kohort restrospektif terhadap 440.655 anak yang mendapat vaksin MMR, 316 anak di antaranya penderita autisme dan 422 anak menderita autisme spektrum disorder. Pada penelitian tersebut dinilai risiko relatif kejadian autisme pada anak yang mendapat vaksin MMR dibandingkan dengan yang tidak mendapat vaksin MMR. Dari hasil ini disimpulkan bahwa tidak ada hubungan kejadian autisme dengan pemberian vaksin MMR. ${ }^{32}$ Gillberg dan Heijbel tahun 1998 di Swedia menganalisis 


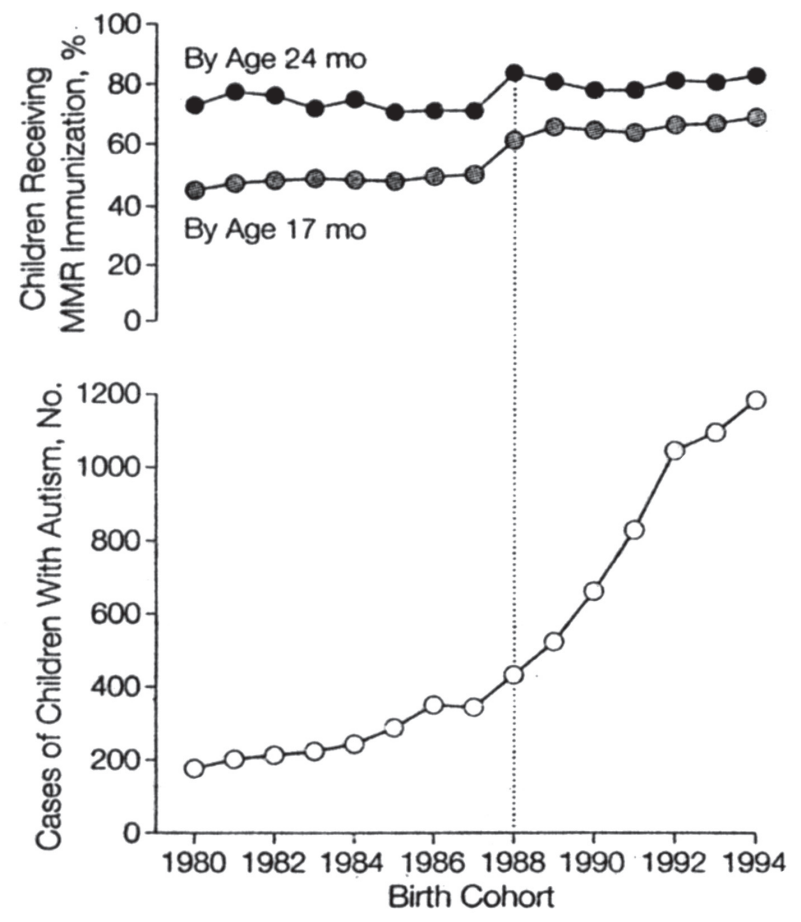

Gambar 3. Hubungan antara anak yang mendapat vaksin MMR dengan kejadian autisme tahun 19801994

Sumber: JAMA 2001; 285:1184 ${ }^{12}$

kembali data dari suatu studi populasi mengenai autisme yang dilakukan pada akhir tahun 1980 dengan membandingkan 2 kelompok anak dari masa pre-
MMR dan pasca MMR (vaksin MMR mulai diberikan tahun 1982 pada anak usia 18 bulan di Swedia), ternyata jumlah kasus autisme pasca MMR justru lebih sedikit dibanding pre-MMR. ${ }^{14}$

Taylor dkk. tahun 2002 meneliti hubungan antara vaksin MMR dan autisme yang dikaitkan dengan inflamasi usus (Wakefield, 1998) pada anak yang didiagnosa autisme antara tahun 1979-1998. penelitian ini merupakan studi terakhir yang berbasis populasi di London Utara. Hasilnya menunjukkan bahwa tidak ada keterkaitan antara MMR dengan bentuk varian baru dari autisme dengan regresi perkembangan anak dan masalah usus besar. Merupakan suatu bukti yang lebih kuat untuk menyatakan tidak adanya keterlibatan vaksin MMR dengan inisiasi autisme. ${ }^{33}$

Tabel 2 menunjukkan rangkuman penelitian yang menghubungkan vaksin MMR dengan kejadian autisme.

\section{Kesepakatan berbagai organisasi tentang hubungan vaksin MMR dengan autisme}

Badan Kesehatan Dunia (WHO) menyatakan bahwa tidak ada hubungan antara vaksin MMR dengan kejadian autisme. Meskipun demikian WHO memperingatkan bahwa kesimpulan ini tidak menyingkirkan kemungkinan vaksin MMR dapat menyebabkan autisme pada sejumlah kecil anak. ${ }^{30}$ Centers for disease control and prevention (CDC)Atlanta mengemukakan bahwa bukti ilmiah yang ada

Tabel 2. Penelitian tentang hubungan vaksin MMR dengan kejadian autisme

\begin{tabular}{|c|c|c|c|}
\hline Sumber & Jenis Penelitian & Subyek yang diteliti (anak) & Kesimpulan Penelitian \\
\hline $\begin{array}{l}\text { Wakefield, dkk., } 1998 \\
\text { (Inggris) }\end{array}$ & Serial kasus & 12 & $\begin{array}{l}\text { Delapan anak menderita autisme yang } \\
\text { diperkirakan karena vaksin MMR. }\end{array}$ \\
\hline Peltoha, dkk., 1998 & Serial kasus & 31 & Tidak ada anak dengan gejala \\
\hline $\begin{array}{l}\text { (Finlandia) } \\
\text { Gilberg \& Heijbel, } 1998 \\
\text { (Swedia) }\end{array}$ & Epidemiologi & 74 & $\begin{array}{l}\text { gastrointestinal yang menjadi autisme. } \\
\text { Kasus autisme setelah pemberian vaksin } \\
\text { MMR lebih sedikit dibandingkan } \\
\text { sebelum adanya vaksin MMR. }\end{array}$ \\
\hline $\begin{array}{l}\text { Taylor, dkk., } 1999 \\
\text { (Inggris) }\end{array}$ & Cross-sectional & 498 & $\begin{array}{l}\text { Tidak mendukung hubungan kausal } \\
\text { antara vaksin MMR dengan autisme }\end{array}$ \\
\hline $\begin{array}{l}\text { The medicines control } \\
\text { agency, } 1999 \text { (Inggris) }\end{array}$ & Serial kasus & 107 & $\begin{array}{l}\text { Belum dapat disingkirkan dugaan } \\
\text { hubungan antara vaksin MMR dan } \\
\text { autisme. }\end{array}$ \\
\hline $\begin{array}{l}\text { Kaye, dkk., } 2001 \\
\text { (Inggris) }\end{array}$ & Epidemiologi & 305 & $\begin{array}{l}\text { Peningkatan kasus autisme lebih } \\
\text { disebabkan kewaspadaan dari }\end{array}$ \\
\hline
\end{tabular}


tidak mendukung hipotesis hubungan MMR dengan autisme. Komitmen CDC Atlanta untuk menjaga keamanan vaksin dan mendukung riset tambahan untuk membuktikan hipotesis tersebut. American Academy of Pediatrics (AAP) secara berkesinambungan merekomendasikan para orang tua untuk memberikan vaksinasi penuh kepada anak-anaknya untuk mencegah penyakit yang berbahaya seperti campak. American Medical Association (AMA) mendukung pendapat yang menyatakan bahwa autisme muncul lebih disebabkan faktor genetik bukan karena vaksin MMR ${ }^{30}$ Penjelasan bersama Departemen Kesehatan RI , Badan POM, IDAI menyatakan bahwa tidak ada kaitan antara kejadian autisme pada anak dengan imunisasi MMR, dan akan terus memantau dan mengkaji efektifitas serta keamanan semua vaksin yang digunakan di Indonesia, termasuk vaksin MMR.

Bukti epidemiologis secara keseluruhan tidak mendukung adanya hubungan antara vaksin MMR dengan kejadian autisme. Meskipun demikian, studi epidemiologi secara metodologis mempunyai keterbatasan untuk mengungkap suatu hubungan sebab akibat, dan tidak dapat menyingkirkan begitu saja kemungkinan adanya hubungan tersebut. Pemaparan terhadap vaksin MMR saat ini terutama di negara maju sudah bersifat universal, untuk dapat menelusuri hubungan dengan akibat yang tidak diinginkan memerlukan riset yang rumit. Autisme adalah penyakit yang sulit ditentukan saat timbulnya secara tepat, maka hubungan waktu antara onset dan vaksinasi dalam desain penelitian epidemiologi sulit ditentukan. ${ }^{30}$

Pada tingkat populasi, bukti-bukti tidak mendukung hubungan kausal antara vaksin MMR dan autisme atas dasar-dasar fakta bahwa bukti epidemiologi secara konsisten tidak menunjukkan adanya hubungan antara vaksin MMR dan autisme pada tingkat populasi, kumpulan kasus-kasus anak autisme dengan gejala usus dan laporan kasus lain kurang informatif untuk mendukung hubungan sebab akibat tersebut, model biologik yang menghubungkan vaksin MMR dan autisme baru bersifat sepotong-sepotong, tidak ada model binatang yang sesuai dalam mempelajari hubungan vaksin MMR dan autisme. ${ }^{30}$

\section{Kesimpulan}

Vaksin MMR merupakan vaksin kombinasi yang telah terbukti dapat menurunkan angka kejadian penyakit gondongan, campak dan rubella serta komplikasi yang dapat ditimbulkannya. Hubungan antara vaksin MMR dengan kejadian autisme masih kontroversial, bukti epidemiologi secara keseluruhan tidak mendukung adanya hubungan antara vaksin MMR dengan kejadian autisme, walaupun WHO memperingatkan bahwa kemungkinan itu masih bisa terjadi pada sejumlah kecil anak.

\section{Daftar Pustaka}

1. Kaye JA, Montes MM, Jick H. Mumps, measles, and rubella vaccine and the incidence of autism recorded by general practitioners : a time trend analysis. BMJ 2001; 322:460-3.

2. Wakefield AJ, Murch SH, Anthony A, Linnell J, Casson DM, Malik M, et al. Ileal-lymphoid-nodular hyperplasia, non spesific colitis, and pervasive developmental disorder in children. Lancet 1998; 351:637-41.

3. Wakefield AJ, Montgomery SM. Measles, mumps, rubella vaccine : through a glass, darkly. Adverse Drug React Toxicol Rev 2000; 19:265-83.

4. Destefano F. Vaccines and Autism. Pediatr Infect Dis J 2001; 20:887-8.

5. Wakefield AJ. MMR vaccination and autism. Lancet 1999; 354:949-50.

6. O'Learry JJ, Uhlmann V, Wakefield AJ. Measles virus and autism. Lancet 2000; 356:772.

7. Singh VK, Lin SX, Newell E, Nelson C. Abnormal measles-mumps-rubella antibodies and CNS autoimmunity in children with autism. J Biomed Sci 2002; 9:35964.

8. Johnson RT, Griffin DE, Hirsch RL. Measles encephalomyelitis, clinical and immunologic studies. N Eng J Med 1984; 310:137-41.

9. Patja A, Davidkin I, Kurki T, Kallio MJ, Valle M, Peltoha H. Series adverse event after measles-mumps-rubella vaccination during a fourteen year prospective follow up. Pediatr Infect Dis J 2000; 19:1127-34.

10. Peltoha H, Patja A, Leinikki P, Valle M, Davidkin I, Paunio M. No evidence for measles, mumps, and rubella vaccine-associated inflammatory bowel disease or autism in a 14 year prospective study. Lancet 1998; 351:1327-8.

11. Taylor B, Miller E, Farrington CP, Petropoulos MC, Mayaud IF, Li J, et al. Autism and measles, mumps, and rubella vaccine : no epidemiological evidence for a causal association. Lancet 1999; 353:2026-9. 
Sari Pediatri, Vol. 6, No. 1, Juni 2004

12. Dales L, Hammer SJ, Smith NJ. Time trends in autism and in MMR immunization coverage in California. JAMA 2001; 285:1183-5.

13. Fombonne E. The epidemiology of autism. Psycol Med 1999; 29(4):769-86.

14. Gilberg C, Heijbel H. MMR and autism. Autism 1998; 2:423-424.

15. Fambonne E, Chakrabarti S. No evidence for a new variant of measles-mumps- rubella induced autism. Pediatrics 2001; 108:991-5.

16. Hadinegoro SRS. Vaksin kombo dan aplikasinya pada jadwal imunisasi. Dalam:Trihono PP, Purnamawati, Syarif DR, Hegar B, Gunardi H, Oswari H, dkk., penyunting. Hot Topics in Pediatrics II. Pendidikan Kedokteran Berkelanjutan Ilmu Kesehatan Anak XLV. FKUI; 2002 18-19 Februari; Jakarta: Balai Penerbit FKUI, 2003.

17. Hadinegoro SRS. Vaksin kombinasi. Dalam: Ranuh IGN, Soeyitno H, Hadinegoro SRS, Kartasasmita C. Buku Imunisasi di Indonesia. Edisi pertama. Jakarta: Satgas Imunisasi IDAI, 2001. h. 147-55.

18. Yeh SH, Ward JI. Strategies for development of combination vaccines. Pediatr Infect Dis J 2001; 20:S5-9.

19. Halsey NA. Safety of combination vaccines : perception versus reality. Pediatr Infect Dis J 2001; 20:S40-4.

20. Matondang CS. Aspek imunologi imunisai. Dalam: Ranuh IGN, Soeyitno H, Hadinegoro SRS, Kartasasmita C. Buku Imunisasi di Indonesia. Edisi pertama. Jakarta: Satgas Imunisasi IDAI, 2001. h. 5-11.

21. American Academy of Pediatricc. Combination vaccines for childhood immunization: recommendations of the Advisory Committee on Immunization Practice (ACIP), the American of Pediastrics (AAP) and the American Academy of Family Physicians (AAFP). Pediatrics 1999; 103:1064-8.

22. Pasaribu S. Campak, Gondongan \& Rubella. Dalam: Ranuh IGN, Soeyitno H, Hadinegoro SRS, Kartasasmita C. Buku Imunisasi di Indonesia. Edisi pertama. Jakarta: Satgas Imunisasi IDAI, 2001. h. 111-7.

23. Maldonado YA. Current controversies in vaccination. JAMA 2002; 288:3155-8.
24. Watson JC, Peter G. General Immunization Practices. Dalam: Plotkin SA, Orenstein WA, penyunting, Vaccines. Edisi ke-3. Philadelpia: WB Saunders, 1999. h. 47-73.

25. Rapin I. Progress in neurobiology of autism. CNS spectrum 1998; 3:50-8

26 Pusponegoro HD. Autisme: bagaimana mengenal dan menegakkan diagnosis. Dalam: Trihono PP, Purnamawati, Syarif DR, Hegar B, Gunardi H, Oswari H, dkk., penyunting. Hot Topics in Pediatrics II. Pendidikan Kedokteran Berkelanjutan Ilmu Kesehatan Anak XLV. FKUI; 2002 18-19 Februari; Jakarta: Balai Penerbit FKUI, 2003.

27. Ritvo ER, Freeman BJ, Pingree C, Mason BA, Jorde L, Jenson WR, et al.The UCLA University of Utah epidemiologic survey of autism, prevalence. Am J Psychiatry 1989; 146:194-201

28. Rapin I. Current concepts of autism. The New England Journal of Medicine 1997; 337:97-103.

29. Lumbantobing SM. Autisme. Dalam: Anak dengan mental terbelakang. Jakarta, Balai Penerbit FKUI, 2001. h. 82-7.

30. Stratton K. Immunization safety review measles-mumpsrubella vaccine and autism. Washington; Institut of Medicine, National Academy Press 2001; 11-55 I. Progress

31. Kawashima H, Mori T, Kashiwagi Y, Takekuma K, Hoshika A, Wakefield A. Detection and sequencing of measles virus from peripheral mononuclear cells from patients with inflammatory bowel disease and autism. Dig Dis Sci 2000; 45:723-9.

32. Madsen KM, Hviid A, Vestergaard M, Schendel D, Wohlfahrt J, Thorsen P, et al. A population-based study of measels, mumps, and rubella vaccination and autism. N England J Med 2002; 347:1477-82.

33. Taylor B, Miller E, Lingam R, Andrews N, Simmons A. Measles, mumps, rubella vaccination and bowel problems or developmental regression in children with autism : population study. BMJ 2002; 324:393-6.

34. Makela A, Nuorti JP, Peltola H. Neurogenic disorder after Measles-Mumps-Rubellla vaccination. Pediatrics 2002;110:957-63 